\title{
Conservation through Biocultural Heritage-Examples from Sub-Saharan Africa
}

\author{
Anneli Ekblom ${ }^{1,2, *}$, Anna Shoemaker ${ }^{1}$, Lindsey Gillson ${ }^{3}$, Paul Lane ${ }^{1,4,5}$ (i) \\ and Karl-Johan Lindholm ${ }^{1}$ \\ 1 Department of Archaeology and Ancient History, African and Comparative Archaeology, \\ Uppsala University, Box 626, SE-751 26 Uppsala, Sweden; anna.shoemaker@arkeologi.uu.se (A.S.); \\ paul.lane@arkeologi.uu.se (P.L.); karl-johan.lindholm@arkeologi.uu.se (K.-J.L.) \\ 2 Natural Resources and Sustainable Development, Department of Earth Sciences, Uppsala University, \\ Villavägen 16, 75236 Uppsala, Sweden \\ 3 Plant Conservation Unit, Botany Department, University of Cape Town, Private Bag X3, Rondebosch 7701, \\ South Africa; lindsey.gillson@uct.ac.za \\ 4 Department of Archaeology, University of Cambridge, Downing Street, Cambridge CB2 3DZ, UK \\ 5 School of Geography, Archaeology and Environmental Studies, University of the Witwatersrand, \\ Johannesburg 2000, South Africa \\ * Correspondence: anneli.ekblom@arkeologi.uu.se
}

Received: 30 November 2018; Accepted: 23 December 2018; Published: 2 January 2019

\begin{abstract}
In this paper, we review the potential of biocultural heritage in biodiversity protection and agricultural innovation in sub-Saharan Africa. We begin by defining the concept of biocultural heritage into four interlinked elements that are revealed through integrated landscape analysis. This concerns the transdisciplinary methods whereby biocultural heritage must be explored, and here we emphasise that reconstructing landscape histories and documenting local heritage values needs to be an integral part of the process. Ecosystem memories relate to the structuring of landscape heterogeneity through such activities as agroforestry and fire management. The positive linkages between living practices, biodiversity and soil nutrients examined here are demonstrative of the concept of ecosystem memories. Landscape memories refer to built or enhanced landscapes linked to specific land-use systems and property rights. Place memories signify practices of protection or use related to a specific place. Customary protection of burial sites and/or abandoned settlements, for example, is a common occurrence across Africa with beneficial outcomes for biodiversity and forest protection. Finally, we discuss stewardship and change. Building on local traditions, inclusivity and equity are essential to promoting the continuation and innovation of practices crucial for local sustainability and biodiversity protection, and also offer new avenues for collaboration in landscape management and conservation.
\end{abstract}

Keywords: biocultural heritage; sub-Saharan Africa; traditional ecological knowledge; hotspots; sacred forests; conservation

\section{Introduction}

Globally, a high proportion of biodiversity resides outside of protected areas. Incentives for biodiversity protection, therefore, must be built and fostered amongst diverse stakeholders, in areas where biodiversity and communities co-exist $[1,2]$. In keeping with this principle, biocultural heritage is an emerging concept drawing on local knowledge, land-use practices and heritage values to define sustainability and resilience from the perspective of local inhabitants [3-10]. The concept is particularly relevant in African contexts, as many landscapes can be defined as continuing cultural landscapes following the International Union for Conservation of Nature (IUCN)'s definition of its category $\mathrm{V}$ 
landscapes as those "where the interaction of people and nature over time has produced an area of distinct character with significant ecological, biological, cultural and scenic value" [11]. In rural areas of Africa, the most common forms of agriculture entail low-intensity land-use practices, often based on various customary systems of access and ownership rights. Globally, there has been increasing realisation that the discontinuation of small scale, low intensity agricultural practices contributes to the recent reductions in biodiversity [12-16]. However, in many African settings environmental debates are still centred on the assumption that local practices of fire management, cultivation and/or grazing cause degradation (for summaries and critiques of such arguments, see, e.g., [17-24]). As will be exemplified here, local low intensity and customary practices may hold the key to strengthening, adapting and re-innovating forms of land-use that accommodate biodiversity and cultural heritage and promote adaptive management and resilience [25]. Building on and reinvigorating such local practices is important given that the effects of climate change are accelerating and climatic insecurity and its effects on food production and security are increasingly pertinent issues [26-28]. At the same time, ongoing competition for land from industrial agriculture, biofuel production, carbon off-setting projects and conservation initiatives make local communities increasingly vulnerable to both climate change and socio-economic transformations that are detrimental to particular livelihood traditions [29-33].

\section{Background}

As an emerging field, biocultural heritage has been explored from different disciplinary perspectives ranging from those focused on socio-cultural practices explored using ethnographic methods, to those rooted in understanding and modelling biological systems on a grand scale $[5,6,9,34,35]$. The origins of the concept can be traced back to the emerging interest in community-based resource management and traditional ecological knowledge in the 1980s [36-39], the adoption of the Convention on Biological Diversity (CBD), and the aftermath of the 2003 IUCN World Parks Conference in Durban, South Africa [4]. The United Nations Educational, Scientific and Cultural Organization (UNESCO) uses the term 'biological cultural heritage' to refer to ecosystems (including habitats and species) originating or developing from human practices [40]. More broadly, biocultural heritage is considered to encompass the natural-cultural components of human-environment interactions including knowledge, practices and innovation. Practices related to biocultural heritage are also closely linked to the construction and confirmation of identities and social cohesion [25,41-45]. Biocultural heritage has been key in developing both local advocacy groups and legal frameworks focused on the protection and ownership of landscapes and resources by and for local communities [4,46-48]. The concept has also been incorporated into conservation biology and broadened to include deep-time landscape history $[7,8,49,50]$.

While there are now several different conceptualisations of biocultural heritage (see, for instance, [4,5]), we draw on the framework developed by Lindholm and Ekblom [50] in defining biocultural heritage as consisting of four interactive elements, each operating at interlinked temporal and spatial scales, that can only be understood through integrated landscape analysis. Ecosystem memories (Figure 1) can be defined as practices and outcomes operating on larger or deep-time scales, where agricultural, grazing and/or fire management activities have reshaped landscapes with long lasting effects on both biological and landscape structures. Landscape memories represent smaller scale materialised human practices and ways of organising landscapes and their outcomes. These include changes in soils, geological formations, flora and fauna but also archaeological sites, built environments and living land-use practices. Local heritage practices and narratives are often interlinked with such land-use activities and play a vital part in maintaining them. Place memories are also defined by local narratives, place names and signs of earlier or continuing practices whose significance is under constant debate and re-negotiation both locally and with external actors. These memory elements will be exemplified in more detail below. The fourth element, stewardship and change, concerns the conceptualisation and transfer of knowledge pertaining to landscape 
management, collaborative innovation and self-determination. The fusion of biodiversity goals with social and economic goals founded on self-determination is essential for establishing ecologically sound and equitable landscape management practices, as we explain below. To identify and explore how and why these four elements intersect requires integrated landscape analysis. These inclusive methodological and conceptual approaches to knowledge and landscape management are essential to both documenting and researching biocultural heritage and applying the insights generated to future stewardship and adaptive practices.

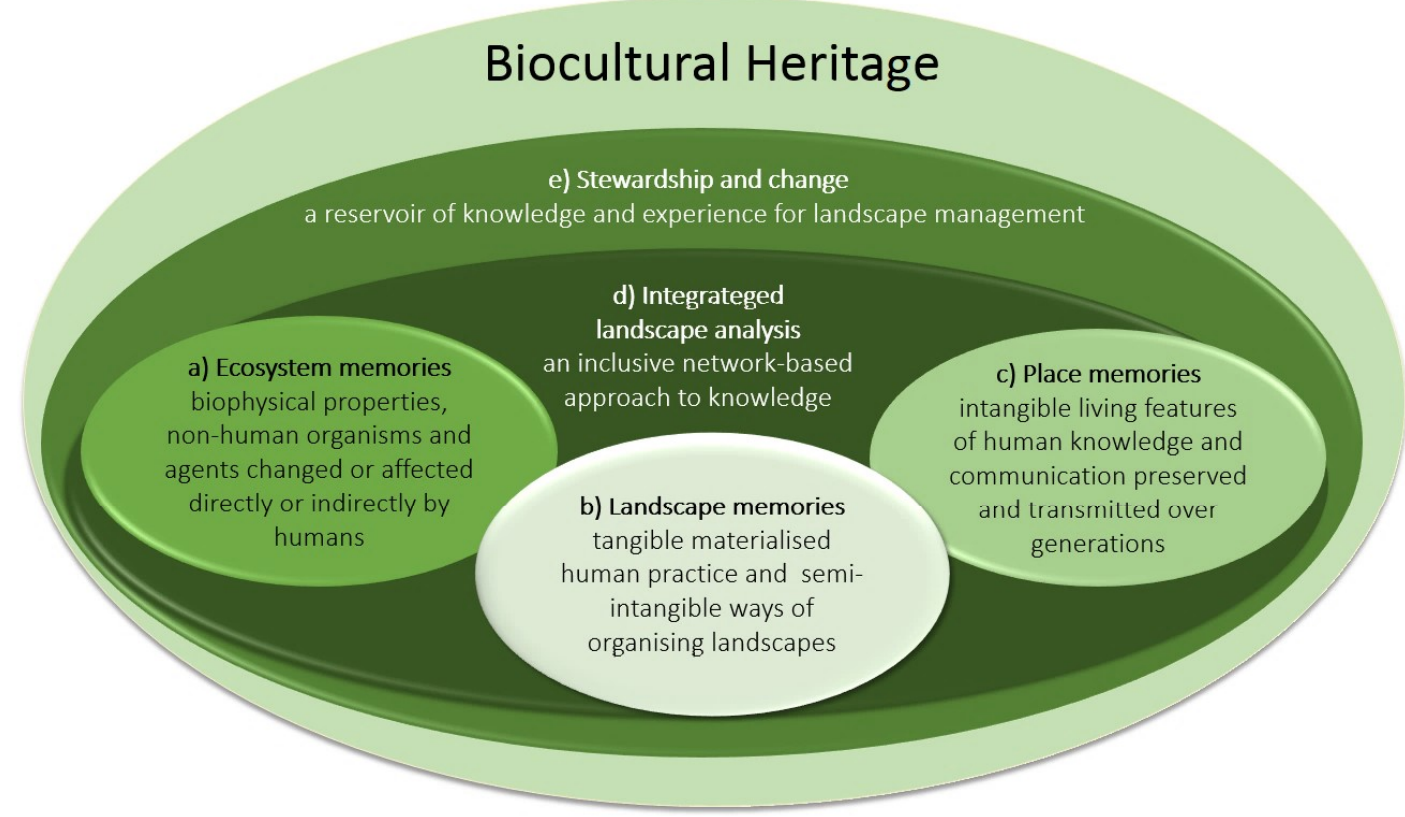

Figure 1. The four 'elements' of biocultural heritage (a-d) as defined by Lindholm and Ekblom [50].

More specifically, integrated landscape analysis is an interdisciplinary toolbox allowing us to trace elements of biocultural heritage and their internal relationships over time, incorporating contemporary botanical surveys, pollen analysis, archaeology, geographical information systems, cartography, historical research and interviews, and participant observation [50]. Studies spanning over both millennia long and shorter timescales have been critical in terms of understanding the biophysical and social ecological aspects of biocultural heritage. Such studies have also been important for re-evaluating degradation narratives that risk impeding effective biodiversity conservation and landscape management practices. A good early example of this is provided by the work of the People, Land and Time in Africa (PLATINA) research group at Stockholm University on deconstructing environmental narratives concerning the origins and drivers of severe soil erosion in Kondoa District, central Tanzania, that had informed colonial and post-colonial interventions for decades (see [51-53] for summaries, and additional references). A deeper understanding of how humans shape landscapes is an essential component in any plan for a sustainable future [7,54-62].

Below we review examples of land-use practices in sub-Saharan Africa, structured around the five interactive elements of biocultural heritage. We combine biological inventories and/or assessments by local residents on the ecological effects of land-use practices, with condensed summaries of archaeology, vegetation history, and interviews with local practitioners. We also complement these with our own and our students' field studies. In none of the cases presented below can the elements of bicultural heritage be understood from one single discipline nor from one single vantage point, whether that is the perspective of a local herder or farmer, researcher, conservationist, development worker or government official. 


\section{Biocultural Heritage in Space and Time}

\subsection{Ecosystem-Scale Memories}

The concept of 'ecosystem memories' comes closest to UNESCO's [40] definition of biocultural heritage as ecosystems developing from human practices. Meadow pastures and wood pastures in Africa can be seen as continuing cultural landscapes, found in savannas and woodlands that are grazing- and fire-dependent [63-66]. Agroforest- and fire- managed landscapes carry structural and species level memories in terms of biological diversity. Interdisciplinary studies are still too few to allow us to assess the performance of these landscapes in terms of biodiversity, but broader scale studies on fire ecology in Africa have shown that landscapes that are fire-managed regularly tend to have both lower intensity and cooler fires that occur earlier in the dry season and which are more beneficial to sustaining biodiversity [65-67]. Fire also plays a crucial part in local landscape management in the semi-dry regions of southern and eastern Africa. In the savanna shrubland of the Chyulu area, Kenya, people burn to improve either hunting or pasture by, in the case of the latter, removing unpalatable grass and ticks. Grazing and dead wood collection are also used to create fire breaks [68]. Such systems are practiced in several regions of southern Africa, but the Chitemene system in Zambia has become particularly renowned for promoting pasture and fertilisation of farms, while also protecting individual trees, and thereby creating fire breaks [69]. In savannas, such mixed fire regimes and patch mosaic burning results in a heterogenous landscape structure comprising a range of post-fire ages, favourable to biodiversity, but managed fires also prevent damaging late season hot fires and uncontrollable wildfires that homogenise landscapes and eliminate fire-sensitive species $[65,66,70]$.

In forested regions, agroforest landscapes create parkland and mosaic landscapes that are structurally diverse and high in agro-biodiversity [71]. The parkland mosaic landscape has a continuity over millennia. Previously, linkages were made between the extent of savannas and parklands and degradation from farming and fire management going back ca. 4000 years. However, palaeoecological studies now suggest climate dynamics have been more important in shaping the distribution of savannas in West Africa over the long term [72,73]. However, humans have also contributed to shaping mosaic landscapes, and fires are an important tool for maintaining landscape structure. In the Koulikoro district of southern Mali, fire is used to create landscape mosaics that increase micro- and edge-habitats, which are favourable for biodiversity. Here, fires and clearings create mosaic landscapes of semi-open areas, fields, fallows, and old growth forests [74,75]. Similarly, in the Kissidougou savanna region in Guinea, West Africa, forest patches and boundaries are continuously protected by households using methods that include mounding (to encourage plant growth), mulching, tilling, planting of crops beneath the trees and protection of tree species [76]. With sufficient fallow periods, such parkland management has positive impacts on tree biodiversity, as has been shown by studies in southwestern Burkina Faso [77]. In East Africa, diverse parkland landscapes are created through a variety of off- and on-farm management and forest protection, resulting in a diversity of trees $[78,79]$. Apart from shaping landscape structure and biology, fire management and shifting agriculture leave memories in terms of soil nutrients. The combination of burning and mulching of soils leads to the formation of black earths $[76,80,81]$. These black earths are conducive to both agricultural and biological diversity, as they are higher in organic carbon, $\mathrm{pH}$, and plant-available nutrients than other local soils, and are also less prone to nutrient leaching or acidification [81].

Another similar example of long-term 'soil memory' important for ecosystems and agrobiodiversity comes from the East African savannas. Historic occupations have resulted in the enrichment of soils from dung and the formation of grassy glades [82-86]. In Kenya, pastoralists recognise these glades as marking former settlement sites and value them for the nutrient-rich grasses, especially Cynodon spp., that recolonize these former 'human' spaces [87,88]. Interviews and archaeological data presented by Shoemaker [89] covering the last ca. 150 years show how these places have been resettled over generations and are preferred sites for settlement. These 'anthropogenic' glades, described by Veblen $[90,91]$ as biological 'hotspots', produce good pasture grasses and are 
functionally important for a range of taxa, including wild megaherbivores [91], but also birds [92,93], geckos, and arthropods (e.g., [94], see also [82,85]). As pastoral communities have been highly mobile over time and soil nutrient compositions can last for millennia [87,88,95-97], the total surface area of such glades is important for overall ecosystem functioning in East African savannas.

\subsection{Landscape Memories}

Landscape memories can be understood as forms of materialised human practice, such as built environments and archaeological sites, including settlement systems and land-use systems linked to user and property rights—what Widgren $[98,99]$ has called 'landesque capital'. Across the continent, there are many examples of irrigation or terracing system landscapes that are relict (see for instance Engaruka in Tanzania [100-102], Nyanga in Zimbabwe [103] and Mpumulanga in South Africa [104]).

In addition to these discontinued terrace systems, there are also landscapes where precolonial irrigation practices are extant (see, for instance, the Mbulu Highlands, Tanzania [105,106]; and the Cheranagni escarpment, Kenya [107]). We will here expand on one example, the furrow irrigation found on the southern slopes of Mount Kilimanjaro, termed mfongo by Chagga-speaking people (Figure 2). The earliest firmly dated irrigation features on Kilimanjaro were built in the 18th century, though oral traditions, historical references, and linguistic evidence indicate that irrigation schemes were present on the mountain by the 17 th century at the latest $[108,109]$. This system, built on customary land tenure, supports multi-layered agroforest gardens high in biodiversity (500 species of which 400 are non-cultivated) $[110,111]$. Despite their productivity and longevity, government policies have long been remiss in terms of promoting and maintaining mfongo practices [108,112,113]. Sunday [114] has explored the continuity and legacy of the mfongo through interviews with 200 households. The practice of making and maintaining water channels is less common today than it was in the remembered past. When asked why mfongo practices are discontinued, local residents replied that increasing droughts and lessened water runoff from Mount Kilimanjaro were the primary causes, although state policies were also mentioned for the wider contextual setting (see also [113]). However, local residents still value the mfongo system for ensuring water access and for maintaining crop yields and diversity. The water channels are also embedded in local heritage and identity. In the interviews conducted by Sunday [114] (p. 48), one elderly woman expressed her worry that this knowledge was now being lost:
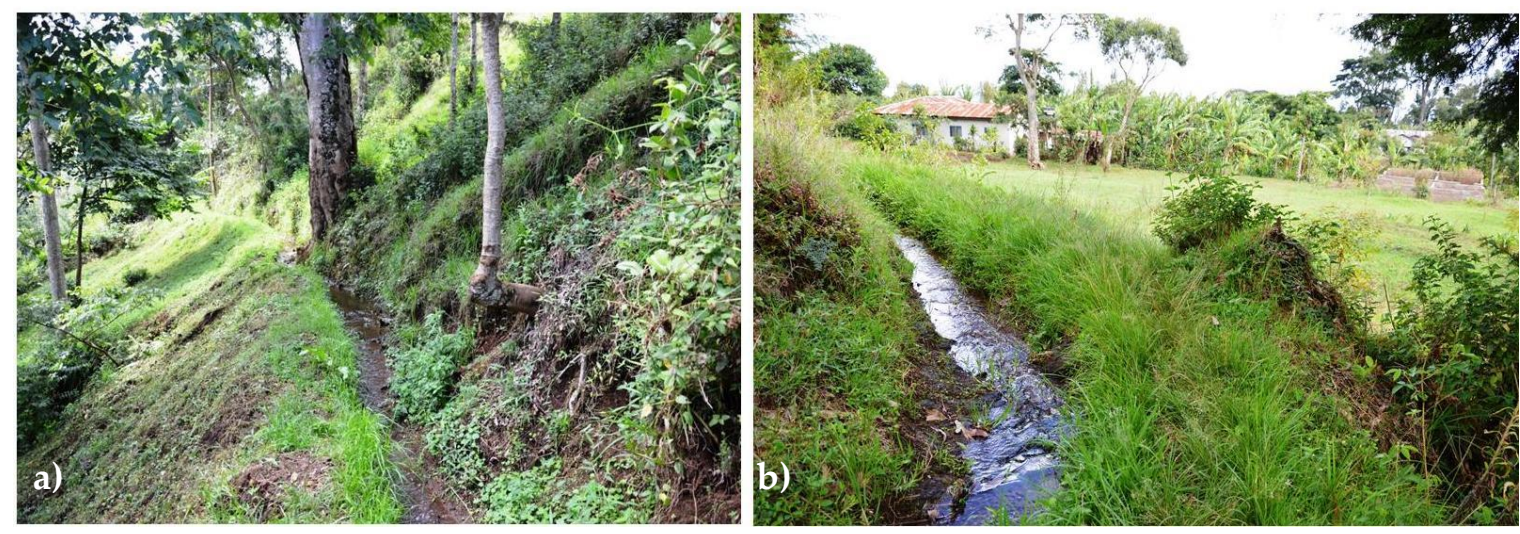

Figure 2. (a) a traditional water furrow (mfongo) cutting across a hillside on Mount Kilimanjaro; (b) a water furrow leading up to a Chagga home garden (photos published by Sunday [114] and reproduced with his permission @ Sabbath Sunday).

"Times have changed very fast! Our children who go to school, when they live in cities for long and God blesses them with children: those children will not produce a generation that will revive culture practices of mfongo and rituals". 
For that woman, and also many other respondents interviewed by Sunday, the making of water channels is more than an agricultural practice, it is also a 'spiritual obligation' and a living knowledge that must be actively maintained.

\subsection{Place-Based Memories}

Place-based memories refer to intangible living features of human knowledge and communication: know-how, place names, orature, arts, ideas and culture, and also biological heritage. A good example is the practice of the protection of 'sacred areas', often ancient and/or community burial areas, or old settlement sites that are surrounded by very strong rules of community protection, some of which have become havens for old growth forests. Though together they may constitute a landscape memory, the foundation of protection is very much placed-based. Sacred sites/forests occur across the African continent, but their potential in terms of biodiversity protection has only been recognised in the last few decades [115-122]. A study in northern Tanzania (the North Pare mountains) located 290 sacred sites. Though small in size, together they covered a total area of 370 ha [123]. Similarly, on Zanzibar there are a great number of sacred areas that are important as reservoirs for the endemic Zanzibar-Inhambane forest phytochoria, which are known to be high in species diversity [124]. Another well-known example is the World Heritage sacred Mijkenda Kaya forests in Kenya. This heritage landscape consists of 11 separated forest islands (growing on abandoned occupation settlements) containing as many as 307 species that are listed as endangered [125,126] (Figure 3). These are sanctuaries for forest-adapted species, both plants and animals, and have been estimated to comprise $4.2-5.6 \%$ of the entire Zanzibar-Inhambane forests mosaic [127]. These sacred areas and the knowledge systems surrounding the activities that brought them into being are as key to the transmission of traditional practices as to the innovation of new ones $[128,129]$.

In the Muzarabani Communal Lands of Zimbabwe (Zambezi valley), forest loss has been shown to be dramatically less in areas considered sacred, or under protection of traditional custodians [130]. Similar observations have also been made in Mozambique in the Licuati forest in the south [131] and the Chôa Highlands in Manica Province. In Chôa, sacred areas have greater species diversity, more complex forest structure, and higher incidence of fire-sensitive species [132]. Palaeoecological techniques have been used in southern Mozambique [133] to study the long-term history of littoral forests, suggesting the existence of mosaic landscapes for 1400 years. Though more studies are needed, it has been suggested that existing forest patches should possibly be re-assessed as having been actively protected through long-term (i.e., over centennial scales) management [133]. Though not supported by palaeoecological data, long-term protection of forest patches has also been suggested for East Africa [134]. In Madagascar, there are also positive examples of customary protection of sacred forest. One example is Ankodida, where protection builds on customary rules surrounding resource use and local custodianship [135]. Such culturally protected small forest islands have been shown to be essential for maintaining ecosystem services [136].

Sacred areas are also common in West Africa. In Benin, 2940 sacred areas have been documented ranging in size from 0.1 ha to 1600 ha, covering a total of 18,360 ha $[137,138]$. Apart from being heritage places, these areas are highly important as biological refugia and function as seed-banks and genetic reservoirs [139]. In numerous regions of Benin, sacred areas can exhibit higher tree species diversity than state-established conservation spaces [140]. Estimates in Ghana suggest there are 2000-3200 such sacred sites [141]. Studies within sacred groves on the Accra Plains found that the biomass and diversity of small mammals often exceed that of surrounding biomes [141]; similar correlations have also been made more recently regarding butterfly populations [142]. In the Loma area in Liberia, dominated by the Upper Guinea forests, sacred areas are often the sites of old towns or graves and the long history and mobility of people and settlements has created a dense network of such sacred areas [143]. Socially proscribed systems of protection surrounding sacred areas allow for the maturation of old growth trees. At the same time, economically important shade-tolerant tree crops (e.g., Kola, cocoa and coffee) can be planted amongst the trees, thriving in the nutrient-dense 
soils that often result from anthropogenic inputs associated with settlements, such as charcoal, animal dung and food refuse. A comparison between the sacred areas and unmanaged fallow areas shows that vegetation in sacred areas is more heterogeneous in the basal layers and higher in the upper layers of the canopy [143].

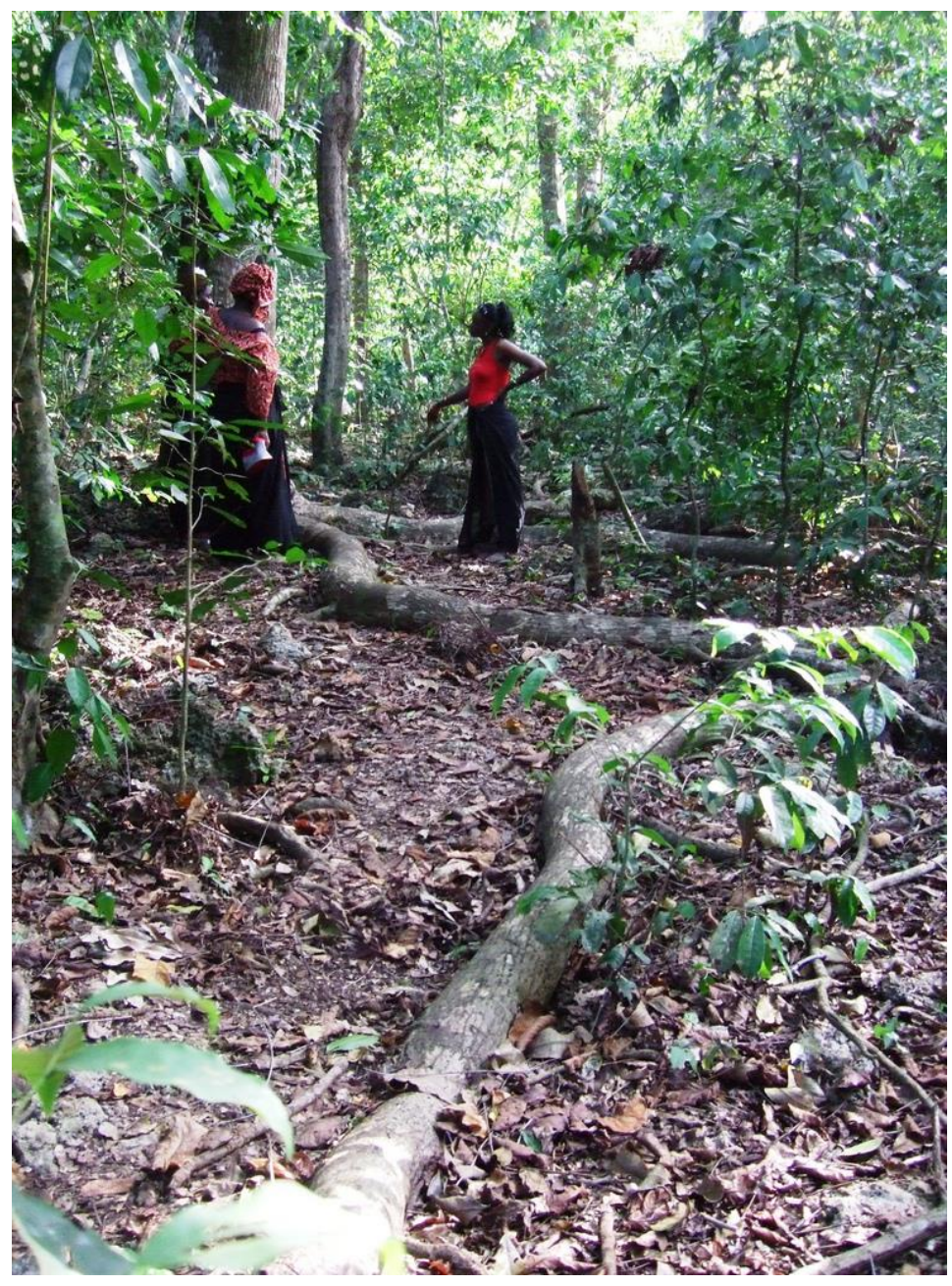

Figure 3. Mijkenda Kaya forests in Kenya (picture from Wikimedia commons, photo by Victor Ochieng @Victor Ochieng).

\section{Discussion: Stewardship and Change}

The memories exemplified above act on different spatial and temporal scales shaping the structure of the ecosystem or landscape. However, the practices that shape them are usually place bound. As physically discernible memories (shown through landforms, vegetation and archaeological and/or heritage sites), they inform practices in the present. Biocultural heritage is closely connected with identity, social cohesion and practice but also social and political negotiation locally $[25,42,43]$. Heritage places, in particular, are often the arena for community meetings where this negotiation is played out. Such events frequently feature the transmission of old and new knowledge [127-129]. Biocultural heritage may then be considered to build on local practices and initiatives, and is therefore key in promoting stewardship, innovation and change $[4-6,9,10]$.

As exemplified in the case of the mfongo system, but also more broadly in the case of fire management [20], state and development policies have tended to work against local practices. After nearly a century of state fire suppression polices across the continent, there is now an expanding body of research calling for better integration of fire management and conservation goals and hence closer 
collaboration between conservation workers and local farmers and pastoralists $[67,74,144]$. For instance, in the Chyulu Hills area of Kenya reviewed above, local residents lament the fact that they are not allowed to pick dead wood or instigate controlled burns around park boundaries, which increases the likelihood of uncontrolled fires within the park, and both local residents and conservationists are stressing the need for collaboration [68]. The Caprivi Integrated Fire Management Programme in Namibia is a positive example here: through collaboration, fire management policies have changed from a centralised fire suppression policy to community-managed fire areas where early season burns are used as a fire management tool by local communities [145].

There is also now a growing awareness of the potential for customary practices and heritage sites to promote forest conservation [119,121,127]. A positive example is the Ankodida forest in Madagascar where the World Wild Fund for Nature (WWF) worked with local residents to incorporate sacred groves into the newly forming protected area network. As communities were concerned that erosion of traditional values was leading to threats to the groves, the formal conservation status was seen as reinforcing cultural taboos promoting the protection of the forest [135]. The Mijkenda Kaya forests in Kenya, discussed above, provide another positive example of stewardship based on local practices of protection and heritage values, where local communities and authorities have collaborated to proclaim the area as a World Heritage Site [127], though as discussed below, there are also problems here with inclusivity and access.

One of the biggest challenges since the emergence of community-based resource management (CBRM) has remained the definition of community itself $[36,146,147]$. Individual community representatives may become a shorthand for 'community', which risks entrenching local power structures that are less than equitable, in particular when it comes to issues related to heritage, often in control of male elders and/or particular lineages. Continuing with the case of the Mijkenda forests, male elders lament the loss of respect for traditions as well as the loss of traditions themselves, processes they believe will ultimately threaten the protection of the sacred forests [127,128]. Meanwhile, based on interviews carried out by Groh [129], youths and women report experiencing issues surrounding access to sacred forest areas, and also the transfer of knowledge and innovations occurring within them during community meetings and ceremonies. For both community leaders and for other local people not so clearly in positions of power, this feeling of exclusion is then a double loss, as crucial knowledge regarding agrobiodiversity and resource use is not being transferred to younger generations (nor women) and the traditions and values associated with forest protection are thus not prioritised by younger community members. Biocultural heritage, while featuring existing (and customary) local practices of land-use and heritage management must therefore also build on principles of inclusiveness and transparency, otherwise it will simply not be accepted by the wider community.

When integrated with principles of equity, justice and representation, while also building on local practices and innovation, biocultural heritage has the promise of combining the goals and aspirations of local residents with the national and international goals of sustainability and biodiversity protection [148]. Concrete collaborations between local communities and conservation in biocultural heritage are still too few and far between, but as argued here, there are ample opportunities to learn from existing local practices of biodiversity stewardship but also from local processes of agrobiodiversity innovation and change. To conclude, in this paper we have discussed a series of cases illustrating how a conceptual framework of biocultural heritage allows for new approaches to heritage, nature conservation, landscape planning and development goals. Biocultural heritage assets, we argue, provide the means to negotiate management goals in these areas, and in certain cases, also to combine them.

Author Contributions: Main author: A.E. Author contributions are as follows: Conceptualization: A.E. and K.-J.L.; Writing-Original Draft Preparation: A.E., A.S.; L.G., P.L.; K.-J.L.; Writing—Review and Editing: P.L., A.S. and L.G.; Visualization: A.E. and K.-J.L.

Funding: The paper has been partly produced within the Adaptation \& Resilience to Climate Change (ARCC) in Eastern Africa project funded by the Swedish Research Council (Vetenskapsrådet), Formas and the Swedish 
International Development and Cooperation Agency (SIDA), grant number 2016-06355, awarded to Paul Lane and Anneli Ekblom. Anna Shoemaker's work was supported as part of the European Commission Marie Skłodowska-Curie Initial Training Network titled "Resilience in East African Landscapes (REAL)" (FP7-PEOPLE-2013-ITN project number 606879, awarded to Paul Lane).

Acknowledgments: This article is a contribution to the Integrated History and Future of People on Earth (IHOPE) initiative (http:/ / ihopenet.org/), and to the Pages LandCover6K and LandUse6K Africa working group activities.

Conflicts of Interest: The authors declare no conflict of interest.

\section{References}

1. Reid, W.V.; Berkes, F.; Wilbanks, T.; Capistriano, D. Introduction. In Bridging Scales and Local Knowledge in Assessments; Reid, W.V., Berkes, F., Wilbanks, T., Capistriano, D., Eds.; Island Press: Washington, DC, USA, 2006; pp. 1-18.

2. Chazdon, R.L.; Harvey, C.A.; Komar, O.; Griffith, D.M.; Ferguson, B.G.; Ramos, M.M.; Morales, H.; Nigh, R.; Soto-Pinto, L.; van Breugel, M.; et al. Beyond reserves: A research agenda for conserving biodiversity in human-modified tropical landscapes. Biotropica 2009, 41, 142-153. [CrossRef]

3. Maffi, L. On Biocultural Diversity Linking Language, Knowledge, and the Environment; Smithsonian Institution Press: Washington, DC, USA, 2001; pp. 1-578.

4. Davidson-Hunt, I.J.; Turner, K.L.; Te Pareake Mead, A.; Cabrera-Lopez, J.; Bolton, R.; Idrobo, C.J.; Miretski, I.; Morrison, A.; Robson, J.P. Biocultural design: A new conceptual framework for sustainable development in rural indigenous and local communities. Sapiens 2012, 5, 33-45.

5. Maffi, L. Biocultural Diversity Conservation: A Global Sourcebook, 2nd ed.; Taylor and Francis: Abingdon, UK, 2012; pp. 3-23.

6. Barthel, S.; Crumley, C.L.; Svedin, U. Bio-cultural refugia-Safeguarding diversity of practices for food security and biodiversity. Glob. Environ. Chang. 2013, 23, 1142-1152. [CrossRef]

7. Cevasco, R.; Moreno, D.; Hearn, R. Biodiversification as an historical process: An appeal for the application of historical ecology to bio-cultural diversity research. Biodivers. Conserv. 2015, 24, 3167-3183. [CrossRef]

8. Gavin, M.C.; McCarter, J.; Mead, A.; Berkes, F.; Stepp, J.R.; Peterson, D.; Tang, R. Defining biocultural approaches to conservation. Trends Ecol. Evol. 2015, 303, 140-145. [CrossRef] [PubMed]

9. Swiderska, K.; Argumedo, A.; Song, Y.; Rastogi, A.; Gurung, N.; Wekesa, C. Biocultural Innovation: The Key to Global Food Security? IIED Briefing, 2018. Available online: http:/ / pubs.iied.org/17465IIED/ (accessed on 29 November 2018).

10. Poole, A.K. Where is Goal 18? The Need for Biocultural Heritage in the Sustainable Development Goals. Environ. Value 2018, 27, 55-80. [CrossRef]

11. IUCN. Cultural Landscapes and Protected Areas. Unfolding the Linkages and Synergies. World Heritage Magazine, 2013. Available online: https:/ / www.iucn.org/content/cultural-landscapes-and-protected-areasunfolding-linkages-and-synergies (accessed on 30 November 2018).

12. Agnoletti, M. Introduction: Framing the issue-A transdisciplinary reflection on cultural landscapes. In Conservation of Cultural Landscapes; Agnoletti, M., Ed.; CABI Publishing: Wallingford, UK, 2006; pp. xi-xix.

13. Agnoletti, M. Rural landscape, nature conservation and culture: Some notes on research trends and management approaches from a (southern) European perspective. Landsc. Urban Plan. 2014, 126, 66-73. [CrossRef]

14. Angelstam, P. Maintaining cultural and natural biodiversity in Europe's economic centre and periphery. In Conservation of Cultural Landscapes; Agnoletti, M., Ed.; CABI Publishing: Wallingford, UK, 2006; pp. 125-143.

15. De Chazal, J.; Rounsevell, M.D.A. Land-use and climate change within assessments of biodiversity change: A review. Glob. Environ. Chang. 2009, 19, 306-315. [CrossRef]

16. Barthel, S.; Crumley, C.L.; Svedin, U. Biocultural refugia: Combating the erosion of diversity in landscapes of food production. Ecol. Soc. 2013, 18, 71. [CrossRef]

17. Richards, P. Indigenous Agricultural Revolution: Ecology and Food Production in West Africa; Hutchinson: London, UK, 1985; pp. 1-192.

18. Richards, P. Coping with Hunger: Hazard and Experiment in an African Rice-Farming System; Allen and Unwin: London, UK, 1986; pp. 1-76. 
19. Fairhead, J.; Leach, M. Misreading the African Landscape: Society and Ecology in a Forest-Savanna Mosaic; Cambridge University Press: Cambridge, UK, 1996; pp. 1-354.

20. Fairhead, J.; Leach, M. Enriching the landscape: Social history and the management of transition ecology in the forest savanna mosaic of the republic of Guinea, Africa. J. Int. Afr. Inst. 1996, 66, 14-36. [CrossRef]

21. Fairhead, J.; Leach, M. Science, Society and Power: Environmental Knowledge and Policy in West Africa and the Caribbean; Cambridge University Press: Cambridge, UK, 2003; pp. 1-272.

22. Ekblom, A. Archaeology, historical sciences and environmental conservation. In Oxford Handbook of Historical Ecology and Applied Archaeology; Stump, D., Isendahl, C., Eds.; Oxford University Press: Oxford, UK, 2015. Available online: http:/ / www.oxfordhandbooks.com/view/10.1093/oxfordhb/9780199672691.001.0001/ oxfordhb-9780199672691-e-9 (accessed on 29 November 2018).

23. Veldman, J.W.; Buisson, E.; Durigan, G.; Wilson Fernandes, G.; Le Stradic, S.; Mahy, G.; Negreiros, D.; Overbeck, G.E.; Veldman, R.G.; Zaloumis, N.P.; et al. Toward an old-growth concept for grasslands, savannas, and woodlands. Front. Ecol. Environ. 2015, 13, 154-162. [CrossRef]

24. Bond, W.; Zaloumis, N.P. The deforestation story: Testing for anthropogenic origins of Africa's flammable grassy biomes. Phil. Trans. R. Soc. 2016, B371, 20150170. [CrossRef] [PubMed]

25. Berkes, F.; Colding, J.; Folke, C. Rediscovery of traditional ecological knowledge as adaptive management. Ecol. Appl. 2000, 10, 1251-1262. [CrossRef]

26. Kotir, J.H. Climate change and variability in Sub-Saharan Africa: A review of current and future trends and impacts on agriculture and food security. Environ. Dev. Sustain. 2011, 13, 587-605. [CrossRef]

27. Niang, I.; Ruppel, O.C.; Abdrabo, M.A.; Essel, A.; Lennard, C.; Padgham, J.; Urquhart, P. Africa. In Climate Change 2014: Impacts, Adaptation and Vulnerability. Contribution of Working Group II to the Fifth Assessment Report of the Intergovernmental Panel on Climate Change; Field, C.B., Ed.; Cambridge University Press: Cambridge, UK, 2014; pp. 1199-1265.

28. Serdeczby, O.; Adams, S.; Baarsch, F.; Coumou, D.; Robinson, A.; Hare, W.; Shaeffler, M.; Perrette, M.; Reinhart, J. Climate change impacts in Sub-Saharan Africa: From physical changes to their social repercussions. Reg. Environ. Chang. 2016, 17, 1585-1600. [CrossRef]

29. Hutton, J.; Adams, W.; Murombedzi, J. Back to the barriers? Changing narratives in biodiversity conservation. For. Dev. Stud. 2005, 2, 341-370. [CrossRef]

30. Brockington, D.; Igoe, J. Eviction for conservation: A global overview. Conserv. Soc. 2006, 4, 424-470.

31. Fairhead, J.; Leach, M.; Scoones, I. Green grabbing: A new appropriation of nature? J. Peasant Stud. 2012, 392, 237-261. [CrossRef]

32. Anseeuw, W. The rush for land in Africa: Resource grabbing or green revolution? S. Afr. J. Int. Aff. 2013, 201, 159-177. [CrossRef]

33. Romeu-Dalmau, C.; Gasparatos, A.; von Maltitz, D.; Graham, A.; Almagro-Garcia, J.; Wilebore, B.; Willis, K.J. Impacts of land use change due to biofuel crops on climate regulation services: Five case studies in Malawi, Mozambique and Swaziland. Biomass Bioenergy 2018, 114, 30-40. [CrossRef]

34. Maffi, L. Cultural, and biological diversity. Ann. Rev. Anthropol. 2005, 34, 599-617. [CrossRef]

35. Pretty, J.; Adams, B.; Berkes, F.; de Athayde, S.F.; Dudley, N.; Hunn, E.; Maffi, L.; Milton, K.; Rapport, D.; Robbins, P.; et al. The intersections of biological diversity and cultural diversity: Towards integration. Conserv. Soc. 2009, 72, 100-112.

36. Agrawal, A.; Gibson, C.C. Enchantment and disenchantment: The role of community in natural resource conservation. World Dev. 1999, 27, 629-650. [CrossRef]

37. Adams, W.; Hulme, D. Changing narratives, policies \& practices in African conservation. In African Wildlife $\mathcal{E}$ Livelihoods: The Promise \& Performance of Community Conservation; Hulme, D., Murphree, M., Eds.; James Currey: London, UK, 2001; pp. 9-23.

38. Dove, M.D. Indigenous People and Environmental Politics. Ann. Rev. Anthropol. 2006, 35, 191-208. [CrossRef]

39. West, P.; Igoe, J.; Brockington, D. Parks and peoples: The social impact of protected areas. Ann. Rev. Anthropol. 2006, 25, 251-277. [CrossRef]

40. UNESCO. Operational Guidelines for the Implementation of the World Heritage Convention; UNESCO World Heritage Centre: Paris, France, 2008; pp. 1-163.

41. Berkes, F. Rethinking community-based conservation. Conserv. Biol. 2004, 18, 621-630. [CrossRef]

42. Olsson, P.; Folke, C.; Berkes, F. Adaptative comanagement for building resilience in social-ecological systems. Environ. Manag. 2004, 34, 75-90. [CrossRef] [PubMed] 
43. Ruiz-Mallén, I.; Corbera, E. Community-based conservation and traditional ecological knowledge: Implications for social-ecological resilience. Ecol. Soc. 2013, 18, 12. [CrossRef]

44. Gómez-Baggethun, E.; Corbera, E.; Reyes-García, V. Traditional ecological knowledge and Global Environemtal Change: Research findings and policy implications. Ecol. Soc. 2013, 184, 72. [CrossRef] [PubMed]

45. Nazarea, D.V. Local knowledge and memory in biodiversity conservation. Ann. Rev. Anthropol. 2006, 35, 317-335. [CrossRef]

46. Swiderska, K. Banishing the Biopirates: A New Approach to Protecting Traditional Knowledge; IIED: London, UK, 2016; pp. 1-24.

47. Chen, C.; Gilmore, M. Biocultural rights: A new paradigm for protecting natural and cultural resources of indigenous communities. Int. Indig. Policy J. 2015, 6, 3. [CrossRef]

48. Bavikatte, K.S.; Bennet, T. Community stewardship: The foundation of biocultural rights. J. Hum. Rights Environ. 2015, 6, 7-29. [CrossRef]

49. Eriksson, O. Historical and current niche construction in an Anthropogenic biome: Old cultural landscapes in southern Scandinavia. Land 2016, 54, 42. [CrossRef]

50. Lindholm, K.-J.; Ekblom, A. A framework for exploring and managing biocultural heritage. Anthropocene 2019, accepted.

51. Payton, R.W.; Christiansson, C.; Shishira, E.K.; Yanda, P.; Eriksson, M.G. Landform, soils and erosion in the north-eastern Irangi Hills, Kondoa, Tanzania. Geogr. Ann. Ser. A Phys. Geogr. 1992, 74, 65-79. [CrossRef]

52. Östberg, W. The Kondoa Transformation: Coming to Grips with Soil Erosion in Central Tanzania; Nordic Africa Institute: Uppsala, Sweden, 1986; pp. 1-99.

53. Lane, P. Environmental narratives and the history of soil erosion in Kondoa District, Tanzania: An archaeological perspective. Int. J. Afr. Hist. Stud. 2009, 42, 457-483.

54. Crumley, C.L. Historical ecology: A multidimensional ecological orientation. In Historical Ecology: Cultural Knowledge and Changing Landscapes; Crumley, C., Ed.; School of American Research: Santa Fe, NM, USA, 1994; pp. 1-16.

55. Crumley, C.L. Historical ecology: Integrated thinking at multiple temporal and spatial scales. In The World System and the Earth System-Global Socioenvironmental Change and Sustainability Since the Neolithic; Hornborg, A., Crumley, C.L., Eds.; Left Coast Press: Walnut Creek, CA, USA, 2007; pp. 15-28.

56. Antrop, M. Why landscapes of the past are important for the future. Landsc. Urban Plan. 2005, 701, 21-34. [CrossRef]

57. Foster, D.R. Conservation issues and approaches for dynamic cultural landscapes. J. Biogeogr. 2002, 29, 1533-1535. [CrossRef]

58. Erickson, C.; Baleé, W. The historical ecology of a complex landscape in Bolivia. In Time and Complexity in Historical Ecology: Studies in the Neotropical Lowlands; Baleé, W., Erickson, C., Eds.; Columbia University Press: New York, NY, USA, 2006; pp. 187-233.

59. Chambers, F.; Daniell, J. Conservation and habitat restoration of moorland and bog in the United Kingdom uplands, a regional, paleoecological perspective. Pages Newslett. 2010, 19, 45-47. [CrossRef]

60. Gillson, L. Biodiversity Conservation and Environmental Change: Using Paleoecology to Manage Dynamic Landscapes in the Anthropocene; Oxford University Press: Oxford, UK, 2015; pp. 87-114.

61. Grove, A.T.; Rackham, O. The Nature of Mediterranean Europe. An Ecological History; Yale University Press: New Haven, VT, USA, 2001; pp. 1-384.

62. Krzywinski, K. Unity in diversity: The concept and significance of cultural landscape for the heritages of Europe. In Cultural Landscapes of Europe. Fields of Demeter, Haunts of Pan; Krzywinski, K., O'Connell, M., Küster, H.J., Eds.; Aschenbeck Media: Bremen, Germany, 2009; pp. 9-22.

63. Scholes, R.J.; Archer, R.S. Tree-grass interactions in savannas. Ann. Rev. Ecol. Syst. 1997, 28, 517-544. [CrossRef]

64. Sankaran, M.; Hanan, N.P.; Scholes, R.J.; Ratnam, J.; Augustine, D.J.; Cade, B.S.; Gignoux, J.; Higgins, S.I.; Le Roux, X.; Ludwig, F.; et al. Determinants of woody cover in African savannas. Nature 2005, 438, 846-849. [CrossRef]

65. Archibald, S.; Staver, A.C.; Levin, S.A. Evolution of human-driven fire regimes in Africa. Proc. Natl. Acad. Sci. USA 2012, 109, 847-852. [CrossRef] [PubMed] 
66. Archibald, S.; Lehmann, C.E.; Gómez-Dans, J.L.; Bradstock, R.A. Defining pyromes and global syndromes of fire regimes. Proc. Natl. Acad. Sci. USA 2013, 110, 6442-6447. [CrossRef] [PubMed]

67. Laris, P.; Dembele, F. Humanizing savanna models: Integrating natural factors and anthropogenic disturbance regimes to determine tree-grass dynamics in savannas. J. Land Use Sci. 2012, 7, 459-482. [CrossRef]

68. Kamau, P.N.; Medley, K.E. Anthropogenic fires and local livelihoods at Chyulu Hills, Kenya. Landsc. Urban Plan. 2014, 124, 76-84. [CrossRef]

69. Eriksen, C. Why do they burn the bush? Fire, rural livelihoods and conservation in Zambia. Geogr. J. 2007, 173, 242-256. [CrossRef]

70. Van Wilgen, B.W.; Govender, N.; Biggs, H.C.; Ntsala, D.; Funda, X.N. Response of savanna fire regimes to changing fire management policies in a large African National Park. Conserv. Biol. 2004, 18, 1533-1540. [CrossRef]

71. Boffa, J.-M. Agroforestry Parklands in Sub-Saharan Africa; FAO: Rome, Italy, 1999. Available online: http: / / www.fao.org/docrep/005/x3940e/X3940E00.htm (accessed on 29 November 2018).

72. Vincens, A.; Schwartz, D.; Elenga, H.; Reynaud-Farrera, I.; Alexander, A.; Bertaux, J.; Marlotti, A.; Martin, L.; Meunier, J.-M.; Nguetsop, F.; et al. Forest response to climate changes in Atlantic Equatorial Africa during the last 4000 years BP and inheritance on the modern landscapes. J. Biogeogr. 1999, 264, 879-885. [CrossRef]

73. Bonnefille, R. Rainforest response to past climatic changes in tropical Africa. In Tropical Rainforest Responses to Climate Change; Bush, M.B., Flenley, J.R., Eds.; Springer: New York, NY, USA, 2007; pp. 117-163.

74. Laris, P. Burning the seasonal mosaic: Preventive burning strategies in the wooded savanna of southern Mali. Hum. Ecol. 2002, 30, 155-186. [CrossRef]

75. Kull, C.A.; Laris, P. Fire ecology and fire politics in Mali and Madagascar. In Tropical Fire Ecology: Climate Change, Land Use, and Ecosystem Dynamics; Cochrane, M.A., Ed.; Springer: New York, NY, USA, 2009; pp. 171-226.

76. Fairhead, J.; Leach, M. Amazonian Dark Earths in Africa? In Amazonian Dark Earths: Wim Sombroek's Vision; Woods, W.I., Teixeira, W.G., Lehmann, J., Steiner, C., WinklerPrins, A., Rebellato, L., Eds.; Springer: New York, NY, USA, 2009; pp. 265-278.

77. Augusseau, X.; Nikiema, P.; Torquebiau, E. Tree biodiversity, land dynamic and farmers strategies on the agricultural frontier of southwestern Burkina Faso. Biodivers Conserv. 2006, 15, 613-630. [CrossRef]

78. Tiffen, M.; Mortimore, M.; GichUnited Kingdomi, F. More People, Less Erosion: Environmental Recovery in Kenya; ACTS Press: Nairobi, Kenya, 1994; pp. 1-309.

79. Backen, M.M. The role of indigenous trees for the conservation of biocultural diversity in traditional agroforestry land use systems: The Bungoma case study. In-situ conservation of indigenous tree species. Agroforest. Syst. 2001, 52, 119-132. [CrossRef]

80. Frausin, V.; Fraser, J.; Narmah, W.; Lahai, M.; Winnebah, T.A.; Fairhead, J.; Leach, M. “God made the soil but we made it fertile": Gender, knowledge, and practice in the formation and use of African Dark Earths in Liberia and Sierra Leone. Hum. Ecol. 2014, 42, 695-710. [CrossRef]

81. Solomon, D.; Lehmann, J.; Fraser, J.A.; Leach, M.; Amanor, K.; Frausin, V.; Kristiansen, S.M.; Millimouno, D.; Fairhead, J. Indigenous African soil enrichment as climate-smart sustainable agriculture alternative. Front. Ecol. Environ. 2016, 142, 71-76. [CrossRef]

82. Blackmore, A.C.; Mentis, M.T.; Scholes, R.J. The origin and extent of nutrient-enriched patches within a nutrient-poor savanna in South Africa. J. Biogeogr. 1990, 17, 463-470. [CrossRef]

83. Augustine, D.J. Long-term, livestock-mediated redistribution of nitrogen and phosphorus in an East African savanna. J. Appl. Ecol. 2003, 49, 137-149. [CrossRef]

84. Augustine, D.J. Influence of cattle management on habitat selection by impala on central Kenyan rangeland. J. Wildl. Manag. 2004, 68, 916-923. [CrossRef]

85. Muchiru, A.N.; Western, D.J.; Reid, R.S. The role of abandoned pastoral settlements in the dynamics of African large herbivore communities. J. Arid Environ. 2008, 72, 940-952. [CrossRef]

86. Muchiru, A.N.; Western, D.J.; Reid, R.S. The impact of abandoned pastoral settlements on plant and nutrient succession in an African savanna ecosystem. J. Arid Environ. 2009, 73, 322-331. [CrossRef]

87. Boles, O.J.C.; Lane, P.J. The Green, Green Grass of Home: An archaeo-ecological approach to pastoralist settlement in central Kenya. Azania 2016, 51, 507-530. [CrossRef] 
88. Petek, N. Archaeological Perspectives on Risk and Community Resilience in the Baringo Lowlands, Kenya; Department of Archaeology and Ancient History, Uppsala University: Uppsala, Sweden, 2018; pp. 1-294.

89. Shoemaker, A. Pastoral Pasts in the Amboseli Landscape: An Archaeological Exploration of the Amboseli Ecosystem from the Later Holocene to the Colonial Period; Department of Archaeology and Ancient History, Uppsala University: Uppsala, Sweden, 2018; pp. 1-320.

90. Veblen, K.E. Savanna glade hotspots: Plant community development and synergy with large herbivores. J. Arid Environ. 2012, 78, 119-127. [CrossRef]

91. Veblen, K.E. Impacts of traditional livestock corrals on woody plant communities in an East African savanna. Rangel. J. 2013, 35, 349-353. [CrossRef]

92. Söderström, B.; Reid, R.S. Abandoned pastoral settlements provide concentrations of resources for savannah birds. Acta Oecol. 2010, 36, 184-196. [CrossRef]

93. Morris, D.L.; Western, D.; Maitumo, D. Pastoralists' livestock and settlements influence game bird diversity and abundance in a savanna ecosystem of southern Kenya. Afr. J. Ecol. 2009, 47, 48-55. [CrossRef]

94. Donihue, C.M.; Porensky, L.M.; Foufopoulos, J.; Riginos, C.; Pringle, R.M. Glade cascades: Indirect legacy effects of pastoralism enhance the abundance and spatial structuring of arboreal fauna. Ecology 2013, 94, 827-837. [CrossRef]

95. Lane, P.J. Archaeology in the age of the Anthropocene: A critical assessment of its scope and societal contributions. J. Field Archaeol. 2015, 40, 485-498. [CrossRef]

96. Shahack-Gross, R.; Marshall, F.; Ryan, K.; Weiner, S. Reconstruction of spatial organization in abandoned Maasai settlements: Implications for site structure in the Pastoral Neolithic of East Africa. J. Archaeol. Sci. 2004, 31, 1395-1411. [CrossRef]

97. Marshall, F.; Reid, R.E.B.; Goldstein, S.; Storozum, M.; Wreschnig, A.; Hu, L.; Kiura, P.; Shahack-Gross, R.; Ambrose, S.H. Ancient herders enriched and restructured African grasslands. Nature 2018, 561, 387-390. [CrossRef]

98. Widgren, M. Towards a historical geography of intensive farming in eastern Africa. In Islands of Intensive Agriculture in Eastern Africa; Widgren, M., Sutton, J.E.G., Eds.; James Currey: Oxford, UK, 2004; pp. 1-18.

99. Widgren, M.; Hakansson, T. Introduction. Landesque capital: What is the concept good for? In Landesque Capital: The Historical Ecology of Enduring Landscape Modifications; Hakansson, T., Widgren, M., Eds.; Routledge: Abingdon, UK, 2007.

100. Sutton, J.E. Irrigation and soil-conservation in African agricultural history: With a reconsideration of the Inyanga terracing Zimbabwe and Engaruka irrigation works Tanzania. J. Afr. Hist. 1984, 251, $25-41$. [CrossRef]

101. Stump, D. The development and expansion of the field and irrigation systems at Engaruka, Tanzania. Azania 2006, 41, 69-94. [CrossRef]

102. Lang, C.; Stump, D. Geoarchaeological evidence for the construction, irrigation, cultivation, and resilience of 15th-18th century AD terraced landscape at Engaruka, Tanzania. Quat. Res. 2017, 883, 382-399. [CrossRef]

103. Soper, R.C. Nyanga: Ancient Fields, Settlements and Agricultural History in Zimbabwe; British Institute in Eastern Africa: London, UK, 2002; pp. 1-277.

104. Widgren, M. Precolonial agricultural terracing in Bokoni, South Africa. J. Afr. Archaeol. 2016, 14, 33-53. [CrossRef]

105. Börjensson, L. A History under Siege: Intensive Agriculture in the Mbulu Highlands, Tanzania, 19th Century to the Present; Stockholm University: Stockholm, Sweden, 2004; pp. 1-187.

106. Börjesson, L. Boserup Backwards? Agricultural intensification as 'its own driving force' in the Mbulu Highlands, Tanzania. Geogr. Ann. Ser. B Hum. Geogr. 2007, 89, 249-267. [CrossRef]

107. Davies, M.I.J. The temporality of landesque capital: Cultivation and the routines of Pokot life. In Landesque Capital: The Historical Ecology of Enduring Landscape Modifications; Håkansson, N.T., Widgren, M., Eds.; Routledge: London, UK, 2004; pp. 172-196.

108. Stump, D.; Tagseth, M. The history of precolonial and early colonial agriculture on Kilimanjaro: A review. In Culture, History Identity: Landscapes of Inhabitation in the Mount Kilimanjaro Area, Tanzania; Clack, T.A.R., Ed.; BAR International Series 1966; Archaeopress: Oxford, UK, 2009; pp. 107-124.

109. Stump, D. The archaeology of agricultural intensification in Africa. In Oxford Handbook of African Archaeology; Mitchell, P., Lane, P., Eds.; Oxford University Press: Oxford, UK, 2013. [CrossRef] 
110. Hemp, A. The banana forests of Kilimanjaro: Biodiversity conservation of the agroforestry system of the Chagga home gardens. Biodivers. Conserv. 2006, 154, 1193-1221. [CrossRef]

111. Hemp, C.; Hemp, A. The Chagga Home Gardens on Kilimanjaro: Diversity and Refuge Function for Indigenous Fauna and Flora in Anthropogenically Influenced Habitats in Tropical Regions under Global Change on Kilimanjaro, Tanzania, Africa. 2008. Available online: https:/ /www.ihdp.unu.edu/file/get/7728 (accessed on 29 November 2018).

112. Chuhila, M.J. Coming down the Mountain: History of Land Use Change in Kilimanjaro, ca. 1920 to 2000 s. Ph.D. Thesis, University of Warwick, Warwick, UK, 2016; pp. 1-349.

113. De Bont, $\mathrm{C}$. The continuous quest for control by African irrigation planners in the face of farmer-led irrigation development: The case of the Lower Moshi Area, Tanzania 1935-2017. Water Altern. 2018, 113, 893-915.

114. Sunday, S. Adaption, Resilience and Transformability A Historical Ecology of a Traditional Furrow Irrigation System on the Slopes of Kilimanjaro. Master's Thesis, Department of Archaeology and Ancient History, Uppsala University, Uppsala, Sweden, 20 December 2015.

115. Decher, J. Conservation, small mammals, and the future of sacred groves in West Africa. Biodivers. Conserv. 1997, 6, 1007-1026. [CrossRef]

116. UNESCO. Conserving Cultural and Biological Diversity: The Role of Sacred Natural Sites and Cultural Landscape; UNESCO: Paris, France, 2005; pp. 1-340.

117. Mgumia, F.H.; Oba, G. Potential role of sacred groves in biodiversity conservation in Tanzania. Environ. Conserv. 2003, 30, 259-265. [CrossRef]

118. Bhagwat, S.A.; Rutte, C. Sacred groves: Potential for biodiversity management. Front. Ecol. Environ. 2006, 410, 519-524. [CrossRef]

119. Sheridan, M.J.; Nyamweru, C. African Sacred Groves: Ecological Dynamics and Social Change; James Currey: London, UK, 2008; pp. 1-230.

120. Metcalfe, K.; French-Constant, R.; Gordon, I. Sacred sites as hotspots for biodiversity: The Three Sisters Cave complex in coastal Kenya. Oryx 2010, 44, 118-123. [CrossRef]

121. Dudley, N.; Bhagwat, S.; Higgins-Zogib, L.; Lassen, B.; Verschuuren, B.; Wild, R. Conservation of biodiversity in sacred natural sites in Asia and Africa: A review of the scientific literature. In Sacred Natural Sites: Conserving Nature and Culture; Verschuuren, B., Wild, R., McNeely, J., Oviedo, G., Eds.; Earthscan: London, UK, 2010; pp. 19-32.

122. Bhagwat, S.A.; Dudley, N.; Harrop, S.R. Religious following in biodiversity hotspots: Challenges and opportunities for conservation and development. Conserv. Lett. 2014, 4, 234-240. [CrossRef]

123. Akida, A.; Blomley, R. Trends in Forest Ownership, Forest Resources Tenure and Institutional Arrangements: Are They Contributing to Better Forest Management and Poverty Reduction? Case Study from the United Republic of Tanzania; FAO: Dar es Salaam, Tanzania, 2006; pp. 1-26.

124. Madewaya, K.H.; Oka, H.; Matsumoto, M. Sustainable management of sacred forests and their potential for eco-tourism in Zanzibar. Bull. FFPRI 2004, 3, 33-48.

125. Schipper, J.; Burgess, N. Tropical and Subtropical Moist Broadleaf Forests: Eastern Africa: Coastal Areas of Kenya, Somalia, and Tanzania. WWF. Available online: http:/ / www.worldwildlife.org/ecoregions/at0125 (accessed on 1 December 2015).

126. Kibet, S. Plant communities, species diversity, richness, and regeneration of a traditionally managed coastal forest, Kenya. For. Ecol. Manag. 2011, 261, 949-957. [CrossRef]

127. Shepheard-Walwyn, E. Culture and Conservation in the Sacred Sites of Coastal Kenya; University of Kent: Canterbury, UK, 2014.

128. Ongugo, P.; Wekesa, C.; Ongugo, R.; Abdallah, A.; Akinyi, L.; Pakia, M. Smallholder Innovation for Resilience SIFOR Qualitative Baseline Study, Mijikenda Community, Kenyan Coast. IIED 2014, 1-35. Available online: http:/ / pubs.iied.org/G03830/ (accessed on 29 November 2018).

129. Groh, M.A. Community Based Adaptations to Climate Change: Experiences of the Mijikenda Community in Coastal Kenya. Master's Thesis, University of Lisbon, Lisbon, Portugal, 30 September 2016.

130. Byers, B.A.B.; Cuncliffe, R.N.; Hudak, A.T. Linking the conservation of culture and nature: A case study of sacred forests in Zimbabwe. Hum. Ecol. 2001, 29, 187-218. [CrossRef]

131. Izidine, S.A.; Siebert, S.; van Wyk, A.E.; Zobolo, A.M. Taboo and political authority in conservation policy: A case study of the Licuati Forest in Maputaland, Mozambique. J. Study Relig. Nat. Cult. 2008, 23. [CrossRef] 
132. Virtanen, P. The role of customary institutions in the conservation of biodiversity: Sacred forests in Mozambique. Environ. Value 2002, 11, 227-241. [CrossRef]

133. Ekblom, A. Forest-savanna dynamics in the coastal lowland of southern Mozambique since $400 \mathrm{AD}$. Holocene 2008, 18, 1247-1257. [CrossRef]

134. Sheridan, M.J. The dynamics of Africa Sacred grooves: Ecological, social and symbolic processes. In African Sacred Groves: Ecological Dynamics \& Social Change; Sheridan, M.J., Nyamweru, C., Eds.; James Currey: Oxford, UK, 2007; pp. 9-41.

135. Virah-Sawmy, M.; Gardner, C.J. The Durban Vision in practice: Experiences in the participatory governance of Madagascar's new protected areas. In Conservation and Environment Management in Madagascar; Scales, I.R., Ed.; Routledge: London, UK, 2014; pp. 240-276.

136. Bodin, Ö.; Tengö, M.; Norman, A.; Lundberg, J.; Elmqvist, T. The value of small size: Loss of forest patches and ecological thresholds in southern Madagascar. Ecol. Appl. 2006, 16, 440-451. [CrossRef]

137. Boussou, B. Sustainable Management of Sacred Forests in Republic of Benin. CBD International, 2011. Available online: http:/ / www.cbd.int/traditional/doc/8jcu-01/2011-06-03-bossou-en.pdf (accessed on 31 March 2018).

138. Alohou, E.C.; Gbemavo, D.S.J.C.; Ouinsavi, C.; Sokpon, N. Local perceptions and importance of endogenous beliefs on sacred groves conservation in South Benin. Int. J. Biodivers. Conserv. 2016, 5, 105-112. [CrossRef]

139. Lokossou, A.O.; Boussou, B. Benin's Experience in the Management of Sacred Forests for Biodiversity Conservation. Available online: http:/ / satoyama-initiative.org/benins-experience-in-the-managementof-sacred-forests-for-biodiversity-conservation/ (accessed on 31 March 2018).

140. Ceperley, N.; Montagnini, F.; Natta, A. Significance of sacred sites for riparian forest conservation in Central Benin. Bois Forêts Troipques 2010, 303, 5-23. [CrossRef]

141. Gordon, C. Sacred groves and conservation in Ghana. In Newsletter of the IUCN SSC African Reptile and Amphibian Specialist Group; IUCN Species Survival Commission: Pretoria, South Africa, 1992; Volume 1, pp. 3-4.

142. Bossart, J.L.; Antwi, J.B. Limited erosion of genetic and species diversity from small forest patches: Sacred forest groves in an Afrotropical biodiversity hotspot have high conservation value for butterflies. Biol. Conserv. 2016, 198, 122-134. [CrossRef]

143. Fraser, J.A.; Diabaté, M.; Narmah, W.; Beavogui, P.; Guilavogui, K.; de Foresta, H.; Junqueira, A.B. Cultural valuation and biodiversity conservation in the Upper Guinea forest, West Africa. Ecol. Soc. 2016, 213, 36. [CrossRef]

144. Donaldson, J.E.; Archibald, S.; Govender, N.; Pollard, D.; Luhdo, Z.; Parr, C.L. Ecological engineering through fire-herbivory feedbacks drives the formation of savanna grazing lawns. J. Appl. Ecol. 2018, 55, 225-235. [CrossRef]

145. Beatty, R. Annexes-CBFiM Case Studies: Annex 1: CBFiM in Namibia: The Caprivi Integrated Fire Management Programme. In Community-Based Fire Management: A Review; FAO: Rome, Italy, 2011; pp. 41-47.

146. Ribot, J.C. Democratic Decentralization of Natural Resources: Institutionalizing Popular Participation; World Resources Institute: Washington, DC, USA, 2002; pp. 1-30.

147. Virtanen, P. Community-based natural resource management in Mozambique: A critical review of the concept's applicability at the local level. Sustain. Dev. 2005, 13, 1-12. [CrossRef]

148. Berkes, F. Community-based conservation in a globalized world. Proc. Natl. Acad. Sci. USA 2007, 104, 15188-15193. [CrossRef] [PubMed]

(C) 2019 by the authors. Licensee MDPI, Basel, Switzerland. This article is an open access article distributed under the terms and conditions of the Creative Commons Attribution (CC BY) license (http:/ / creativecommons.org/licenses/by/4.0/). 